\title{
1. Towards a market oriented university
}

In an ideal world universities would not have to compete for students. There would be no need to set fees. Instead, government would fully fund the higher education system allowing universities to focus their time, energy and resources on research and teaching and other activities they deemed important. Of course the world is far from ideal and the reality is that universities now operate in an environment that is changing rapidly. Technological advances are heralding new online educational platforms from non-traditional providers; rating agencies are becoming increasingly more influential, and the government wants more return on its investment while at the same time reducing funding into the sector.

We begin this book by examining the impact of government on the higher education sector. As the main underwriter of higher education systems around the world, governments everywhere have a profound interest in the performance of universities. Governments expect to see a return on their investment; they want a university system that earns export dollars through international student fees; that contributes to solving society's problems through innovative research; and provides industry and the professions with a supply of well-educated graduates that are able to contribute to the economic growth of the nation. To achieve these aims, government funds the higher education sector and sets out the rules for universities to operate within.

As we shall demonstrate in this chapter, the primary impetus for the emergence of the market oriented university is not the university sector and its leaders, it is the constant evolution of higher education policy under successive governments of all political persuasions. We confine our overview of higher education policy to Australia and the UK. The US higher education system is a mixture of publicly funded state university systems, private universities, such as Stanford, Harvard and Duke, and for-profit institutions, such as the University of Phoenix. While there is a Department of Education, education policy in the USA is decentralized, with higher education standards varying by state and institution. Quality is maintained using a peer-reviewed process through independent accrediting organizations that have developed standards of excellence. 
Higher education institutions are required to reaccredit on a regular cycle, typically every 5-7 years depending on the requirements established by the accrediting organization. US state-funded university systems are somewhat analogous to their counterparts in Australia and the UK, hence our focus on the latter two for the purposes of the analysis.

Within the UK the government recently allowed universities to set their own fees for domestic students up to a maximum of $£ 9,000$. The rationale is that enabling universities to charge their own fees provides more competition and better value for students. Whether this will be achieved is debatable, as the majority of universities have elected to charge the maximum allowable. ${ }^{1}$

Prior to 2008, the Australian government set a 'cap' on the number of publicly funded places that it would fund. This policy enabled the government to control the level of expenditure. From 2012 onwards the government 'lifted the caps' and agreed to fund places for every undergraduate domestic student admitted to a public university. Rather unsurprisingly this led to an increase in the number of students from 444,000 to 541,000 and an increase in government expenditure from $\$ 4.6$ billion in 2009-10 to an estimated $\$ 7.2$ billion in $2016-17 .^{2}$ To address these budgetary challenges, the government attempted to enact legislation that would result in a 20 per cent reduction in funding for universities; allow universities to set their own fees with no maximum price; provide government support to qualifications below bachelor degrees, and also to private universities and non-university providers. In sum, the signal from the government is that the higher education sector is entering a new era that can be characterized as reduced government support, increased costs for students, increased competition from the private sector and increasing customer expectations. Returning briefly to the USA, its state-funded higher education institutions are facing similar challenges in the wake of successive state-level tax reforms that have reduced public funding. Furthermore, federal government intransigence and budget conflicts have reduced federal support for university research activities, putting pressure on public and private institutions alike to seek alternative research funding support beyond the government. ${ }^{3}$

The fact that government views a market driven approach as solving issues in higher education is a non-trivial issue. Senior leaders in higher educational institutions may be asking themselves whether a market driven approach is a permanent feature of government policy. We believe that the answer is a resounding yes and that, if anything, future government higher education policy will be even more market driven. We base this upon the following overview of higher education policy in Australia and the UK. Thus, the purpose of this chapter is to provide an overview 
of the evolution of higher education policy, particularly in Australia, and in part the UK. What we shall demonstrate is that the concept of higher education as a public good has been gradually replaced with a view that the main beneficiary of higher education is the individual recipient who through the attainment of university qualifications is able to improve their career prospects and life chances. This focus upon the individual consumer has shaped the direction of higher education policy, within both Australia and the UK, and overseas. For a long time, government higher education policy has been moving inexorably towards a predominantly market based higher education system, in which the allocation of resources is determined by the end user, the student-consumer, and whereby individual providers compete for students based upon a combination of factors such as price, quality, reputation, location, delivery mode and customer satisfaction. We choose Australia and the UK because these two countries have and continue to undergo considerable market driven change in their higher education sectors. The conclusion we draw based upon our review is that there is no turning back. In short, there is little hope that future governments in these two countries will reverse this policy direction regardless of political ideology. The message for the higher education sector is loud and clear, that to survive under such a policy framework requires universities to begin viewing students as consumers and each other as competitors.

For senior leaders in universities and for those charged with the responsibility of developing the strategy and the marketing efforts of the institution we believe that a thorough understanding of the evolution of higher education policy and the political framework is necessary to appreciate the imperative for universities to adopt a market oriented approach. In sum, if there are any university leaders and administrators reading this that are waiting to hear that the government is looking to put more money into higher education, this chapter will dispel that notion once and for all.

\section{EVOLUTION OF HIGHER EDUCATION POLICY IN AUSTRALIA}

Similar to religious institutions, universities are great survivors. Although there is some disagreement over the exact dates, it is generally held that the first university in the Western world was the University of Bologna, Italy, founded in or around 1088. Of 66 institutions that were in existence in the sixteenth century, 62 of these are universities. ${ }^{4}$ Within Australia the first university was the University of Sydney, established in 1852, and awarded its first degrees in $1856 .{ }^{5}$ The University of Melbourne was established soon after, with its first classes commencing in 1855 , making both 
universities older than all of the universities in England except Oxford, Cambridge, Durham and London. ${ }^{6}$ By 2012, Australia had 39 universities, enrolling more than one million students, and employing over 100,000 staff. $^{7}$ In that period of time, the higher education sector in Australia has undergone profound change, from one controlled and heavily funded by government, to one that is moving towards a fully-fledged market based system, characterized by student demand determining which courses are to be offered, and which institutions will offer them. In the following section we briefly review some of the influences that have shaped government policy in Australian higher education, with particular reference to key government inquiries into higher education. For those readers that find history and politics less than fascinating, you can skip to the end of this chapter for a summary and conclusion. However, if you are keen to learn how higher education policy has been shaped over the years, our 'Cook's tour' of various reviews of higher education in Australia and the UK provides an understanding of how policy is shaped and why future policy initiatives will continue to be market driven.

\section{THE MURRAY COMMITTEE 1957}

The Prime Minister of Australia, Robert Menzies, appointed Sir Keith Murray of the UK University Grants Commission to conduct an inquiry into Australian universities. The terms of reference required the committee to investigate a broad range of issues related to universities, including the role of the university in the Australian community, technological education and the 'financial needs of universities and the appropriate means of providing for those needs' ${ }^{8}$ The Prime Minister arguing that the 'educational crisis was of paramount significance' and that it was hoped that the committee would provide advice as to 'how best the universities may serve Australia at a time of great social and economic development within the nation'. ${ }^{9}$ It was not only the development within the nation that was causing concern in government circles. Scientific progress in the Soviet Union, such as the development of Sputnik, made it imperative that Australia was not left behind in the East-West power struggle. ${ }^{10}$

The Murray Committee invited formal submissions from each university, and other various associations and organizations with an interest in higher education. The committee received responses from staff associations, the Vice Chancellor's committee, but there was relatively little input from industrial, commercial and professional organizations ${ }^{11}$ and there appears to be no input received, or sought, from the students or their parents. The input received from the academic community reflected an 
insular, elitist view of education, as evidenced by the submission from the Vice Chancellor's committee, AVCC, that the universities had been forced 'to make some concessions to the pragmatic public reflected in the development of law, medicine and engineering. ${ }^{.12}$

Given the breadth of the terms of reference it is remarkable that the five members of the committee were able to achieve their task in only a three-month time frame. The Murray Committee reported in November 1957, and noted in its report that as a nation, Australia has significant disadvantages due to its small population, and great physical distances, resulting in high production costs. In the view of the committee, the only way to address such challenges was through the 'efforts of experts in every area'. ${ }^{13}$ Moreover, in what was to prove to be a recurring theme for the higher education sector, the report suggested that almost every problem is financial. To the relief of the academic community the report recommended a 'national approach to university planning and a major continuing financial role for the Commonwealth'. ${ }^{14}$ The Prime Minister expressed his delight with the findings of the report, noting that the report was 'brilliant' and 'provocative' and represented a 'new and brighter chapter in the history of Australian universities'. ${ }^{15}$ Given such an effusive response from the Prime Minister, it was no surprise that the bulk of the Murray Committee's recommendations were accepted and quickly implemented.

The Murray Committee of 1957 had a profound impact upon the future of higher education in Australia. Indeed, it has been stated in reference to the Murray Committee that the year 1957 'was a watershed'16 and that the presentation of the report to Parliament by the Prime Minister in the last week in November 1957 was an 'event unique in the history of Australian education'. ${ }^{17}$ Prime Minister Menzies, it is argued, regarded the adoption of the Murray Committee's report as the crowning achievement of his political career. ${ }^{18}$ Although this may be poetic licence on the part of some commentators, this should not diminish the significance of the report. In a little over three months, the five members of the Murray Committee managed to produce a report that would pave the way for a greater involvement of the federal government, recommend a stronger financial base for the universities and, most importantly, further clarify the link between higher education and the economic and social welfare of the nation. It has been argued that the adoption of the recommendations of the Murray Report laid the foundations for the modern university system in Australia, with the activities and standards requisite for membership of the 'international community of universities'. ${ }^{19}$ 


\section{THE MARTIN COMMITTEE 1964}

Prime Minister Robert Menzies appointed the Martin Committee with the task of considering the pattern of tertiary education in relation to the needs and resources of Australia. Echoing the terms of reference to the Murray Committee, the committee was given the task of finding solutions for the problems of providing tertiary education 'within financial limits which are very much more modest than under our present university system'. ${ }^{20}$ Menzies believed that expanding the university system in Australia could be problematic, given the expenses associated with a university education. Menzies was also concerned that expanding the university system would result in a dilution of academic standards, which may explain his choice of Sir Leslie Martin to chair the committee. Martin was known to be a conservative, holding elitist views on the role of the university. ${ }^{21}$ However, contrary to Menzies's expectations the commission's interim report suggested that the number of universities would need to be increased. Given the financial difficulties facing the government at the time, along with the fact that there were few votes in expanding the number of universities, Menzies made it clear to Martin and the committee that it was unlikely that there would be further funding to expand the university system, and so a new solution would be needed to accommodate a growing higher education sector. ${ }^{22}$

After undertaking a comprehensive three-year review of Australian higher education, the Martin Committee report stated that higher education in Australia should be available to all citizens according to their inclination and capacity, that this view accords with the aspirations of individuals and serves the needs of the community in promoting dynamic economic growth. The committee acknowledged what it perceived to be the differing levels of academic ability of individuals, by proposing three categories of tertiary institution: (1) universities; (2) colleges or institutes; (3) teacher training facilities. This model was designed to preserve the elite nature of universities while simultaneously meeting the needs of industry through the colleges.

Although the government rejected the idea of the teacher training facilities it accepted the broad recommendations of the committee, in particular that a non-university sector should be created to meet the increasing demand for higher education. These new colleges, to be known as colleges of advanced education, would be more vocationally oriented, in contrast to the universities that were to focus on the development of knowledge and research. Moreover, the colleges were not to offer degrees, or attempt to become universities. Instead, they were to offer education to diploma level.

The colleges of advanced education were supposed to be 'equal but 
different' and in reality were a cheaper substitute to the universities. Senator John Gorton, who was not a university graduate, gave strong support for the proposed binary system, and the colleges of advanced education came into being in $1965 .{ }^{23}$ In keeping with the recommendations of the Martin Committee the colleges were not funded to undertake research. The colleges were to prove successful in that 70 per cent of the increase in higher education enrolments during the period 1977-87 was within the colleges. ${ }^{24}$ The Martin Committee had laid the foundations for what would later be known as the binary system. It is interesting to note that although Martin believed that the colleges would account for future growth in higher education, by the mid 1970s nine additional universities had been added to the system. ${ }^{25}$

One of the striking aspects of the Martin Committee is the language and philosophy that permeates the report. The report was written at a time when the economics of education was emerging as an important area of study worldwide. The widely held view was that an increase in the number of graduates would have a positive improvement on the national economy. ${ }^{26}$ According to the Martin Committee, national survival was dependent upon a pool of talented young people with 'opportunities to develop their innate abilities to the maximum'. ${ }^{27}$ Rather presciently, the Martin Committee pointed out that generally speaking, an individual who is more highly educated will both contribute more to society's production than their lesser educated counterpart, and also be more highly remunerated. Similarly, the Martin Committee adopted a free market approach to higher education, stating: 'conflicts between students' aspirations and community needs should be allowed to be resolved by the operation of supply and demand'. ${ }^{28}$ In referring to supply and demand, the Martin Committee also acknowledged that a substantial increase in the extent of higher educational programmes would reduce the premium rewards enjoyed by graduates, thus rendering the expansion of the university system unattractive from the view of the self-interested individual.

The Martin Committee recommendations were broadly accepted and implemented by the government, thus ensuring that the next 25 years of higher education in Australia would be characterized by a binary system, with universities and colleges of advanced education that were supposedly 'equal but different'. How equal and how different would depend on which side of the binary divide one sat on. In line with the philosophy underpinning the Murray Committee, the Martin Committee emphasized the link between higher education and the economy. Moreover, the Martin Committee made clear that graduates receive higher rewards than non-graduates, a point that would be built upon by future governments to further alter the higher education system. 


\section{THE DAWKINS REVIEW 1987}

In 1972, the incoming Prime Minister, Gough Whitlam, leader of the Australian Labour Party, implemented an election promise to make higher education free by abolishing tuition fees, and for the federal government to take financial responsibility for universities and colleges of advanced education from the state governments. ${ }^{29}$ The Whitlam government was short-lived and was defeated in 1975. There then followed what has been termed as an 'era of higher education neglect', as successive governments were faced with severe budgetary deficits, resulting in an inevitable decline in higher education funding from 4.5 per cent to less than 3 per cent of total federal budgetary outlays. ${ }^{30}$

Given that the majority of funding for higher education in this period was the responsibility of the federal government, budgetary issues were always going to have a significant impact upon the welfare of the sector. The period during the 1980s was one in which the Australian economy was facing challenging times. This point was highlighted in one of the more memorable and defining points of the era when the then Treasurer, Paul Keating, was interviewed on a popular radio station. In reference to what was then Australia's worst current account deficit, Paul Keating told the audience that Australians needed to know what sort of a 'hole' Australia was in, and that there was a danger Australia would become a 'banana republic'. Keating's provocative outburst led to financial markets going into a tailspin and the Australian dollar falling by 10 cents in the aftermath. ${ }^{31}$

The government was focused on restructuring the Australian economy to make it internationally competitive, and this would include the various elements that comprised the public sector. The government had taken the decision to float the Australian dollar, and the dollar was floated on Monday 12 December 1983, which would eventually lead to deregulation of the financial industries, the freeing up of tariffs and a variety of structural reforms to the Australian economy. The period in the mid 1980s was one in which 'Reaganomics' in the USA and 'Thatcherism' in the UK were the dominant political paradigms. This did not go unnoticed in Australia, with economic policy strongly influenced by the ideology of the New Right'. ${ }^{32}$ With the success of these approaches overseas, policy makers in Australia were more predisposed towards free market principles, with an emphasis towards 'privatization' solutions. ${ }^{33}$ It became abundantly clear that the higher education sector was not going to completely escape the reforms that were taking place in other sectors of the economy. With a view to improving the competitiveness of Australia, the need to increase the skills and qualifications of the Australian workforce could only be 
achieved through an expansion of the higher education sector, minus the associated costs. In short, in 'the coordinating departments of Treasury, Finance and Prime Minister and Cabinet a consensus emerged that Australia should expand tertiary participation but could no longer afford free tertiary education' ${ }^{34}$

Thus, the higher education sector was deemed to be ripe for restructuring, with a commitment to strengthening the links between employment and education. The appointment of the Minister for Trade, Mr John Dawkins, to the newly created Department of Employment, Education and Training (DEET) would herald a seismic shift in the higher education sector. The first indicator of the new direction that education would take was given when Minister Dawkins insisted that the word 'Employment' was placed first in the Department's title, to convey that the primary role of education was to make a contribution to the Australian economy. ${ }^{35}$ Given the success that Dawkins had achieved as Minister for Trade 1984-87, where he had persuaded higher education institutions to earn extra revenue through the recruitment of full-fee paying overseas students, ${ }^{36}$ he was a perfect choice to 'shake up' the system. Dawkins quickly implemented changes, abolishing the Schools Commission and the Commonwealth Higher Education Commission, and set about pursuing an ambitious reform agenda. The general direction that Dawkins would take was signalled in an early address.

In a climate of fiscal constraint, and with the economic difficulties we are experiencing, governments have a legitimate role in ensuring that broad national priorities are reflected in the activities of higher education institutions. Similar requirements exist in all other areas of public administration, and higher education institutions cannot expect to receive ever-increasing funding in the form of untied and unconditional grants, with the Government merely acting as banker and post office. ${ }^{37}$

As far as Dawkins was concerned, the higher education sector could no longer see itself as being a 'special case' with government providing unlimited and unrestricted funds to the sector. Dawkins was enunciating what would become the future view of successive governments; that education was to serve the national interests, with an increasing expectation that higher education would more closely align its priorities with those of the nation. Acknowledging the federal budget deficit, and with the knowledge that the higher education sector was reluctant to accept change, Dawkins delivered his first ministerial statement within two months of taking office, ${ }^{38}$ in which he emphasized the broader role of higher education in relation to the government's cultural, social and economic objectives. This statement was quickly followed up in December 1987 with the Higher 
Education Policy discussion paper (Green Paper). The proposals set forth in the Green Paper were nothing less than radical, and would have caused enormous angst for the Vice Chancellors of the established universities and outpourings of joy from the leaders of the colleges of advanced education.

The Green Paper was formulated within the context of an Australian economy that was experiencing difficult times. As the paper pointed out, Australia finds itself 'in a world in which the times have turned sharply against us' ${ }^{39}$ Australia's poor economic performance was highlighted with a high budget deficit, weakening balance of trade, higher inflation and unemployment. With an over-reliance on commodity exports, a weakening manufacturing sector and an economy in need of microeconomic reform ${ }^{40}$ the rationale for reform was self-evident to Dawkins. Accordingly, the Green Paper was in part a response to deterioration in the fortunes of the nation. In the foreword to the Green Paper, Dawkins states:

Australia must now examine the performance of its higher education system. We must ask the people and companies of Australia, whose taxes provide the resources for higher education, what demands and expectations the country has of its institutions and whether the institutions are responding to those demands and expectations. ${ }^{41}$

As Dawkins pointed out in the Green Paper, Australia could no longer see itself immune from the vicissitudes of the global economy. Barriers to communication and remoteness were being steadily removed in the cultural, technological and economic revolutions that were taking place worldwide. Australia needed to become more competitive and in this new era universities would be expected to make a contribution for the tax monies they were receiving, and ensure that such contributions were supportive of the broader needs and goals of the Australian community.

Dawkins was prescient in noting that the Australian economy needed to recognize that it was unsustainable to rely on industries such as mining and agriculture. Instead, argued Dawkins, the Australian economy had to embrace areas such as advanced manufacturing and new service industries. Dawkins argued that although it was not possible to predict the future structural changes to the economy with any degree of certainty, it was clear that Australia needed an educated workforce that was able to adjust to external shocks, thus protecting Australia's standard of living. ${ }^{42}$ Similarly, for individuals looking to prosper in a fast changing world, qualifications were the 'ticket' to ensuring success in a volatile and unpredictable labour market. In one sense it can be argued that Dawkins was suggesting that in the future, Australia needed to rely not on its resources, but its resourcefulness.

While Dawkins pointed out the external threats facing the Australian 
economy, he also flagged the need for the higher education sector to undergo significant structural change. In what was probably a shock for the leaders and academics of Australia's universities, Dawkins proposed a new national unified system. To become a member of the new system an institution had to have a minimum level of enrolments. If an institution could not meet this threshold, it could merge with a similar institution. Under these circumstances, the 'new' institution would have a single management structure and a single educational profile. To encourage participation, the 'carrot' being offered was the opportunity to benefit from 'liberalised resourcing arrangements and a share of the growth in the system'. The alternative, being the metaphorical 'stick' was that 'those institutions that chose to remain outside of the system will have no guaranteed basis of Commonwealth funding'. ${ }^{43}$ The immediate effects of this proposal were that there would be a number of amalgamations between smaller institutions. However, of far more significance was that this proposal would eventually set in motion the initiative to transform the colleges of advanced education into universities. This was despite Dawkins himself stating that in relation to nomenclature of institutions, titles such as college of advanced education 'should not be set aside lightly'. ${ }^{44}$

It wasn't just the 'big picture' issues that attracted the interest of Dawkins. He also focused on micro reform of the sector, especially the governance and management of the institutions. The Green Paper identified that higher institutions were in many ways equivalent to large organizations, with multi-million dollar budgets. Given this, Dawkins proposed changes to membership of the institutional governing body, in order to facilitate better decision making and accountability to governments, employers, students and the community. It was not only the highlevel administrative bodies of the university that were told they needed to change. The report also pointed out the need for better managers, efficiency gains, corporate planning and a client focus. To achieve these goals would require academic managers with the appropriate leadership and administrative skills similar to their counterparts in the business world. It was unlikely, the report argued, that such talented individuals would be appointed, if academics were allowed to elect their own leaders. In short, higher education institutions had significant challenges ahead of them, and from this point forward a more business-like approach would need to be adopted. In arguing for a corporate managerial approach ${ }^{45}$ the report was basically affirming that higher education institutions were too important to the national interest to be allowed to continue to be led and managed by 'amateur managers'. The future leaders of Australia's higher education institutions would need to have well-developed management 
skills and an understanding of the importance of meeting the needs of the various stakeholders.

Of all the issues raised in the Green Paper, the one that would change forever the landscape of the Australian higher education sector, and indeed, would have an impact throughout other higher education systems overseas, was 'buried' on the final page of the document, under the heading, 'Other funding options'. Although the report noted that institutions now had a variety of sources from which to raise revenue, it recognized that there was a need for more funding to be found for the sector, and that it was highly unlikely that government would provide any extra revenue. Instead, the report suggested that perhaps students, former students and/or their parents could make a financial contribution. The rationale behind this suggestion was that graduates of higher education receive, on average, higher earnings than non-graduates, and thus are the primary beneficiaries. Similar to the views expressed by the Martin Committee, there was a strong emphasis upon the private as opposed to the collective or public benefits of higher education, thus paving the way to 'marketized' higher education. ${ }^{46}$ To deal with this complex issue, the report announced the establishment of the Wran Committee on Higher Education Funding to examine possible options, and that the committee would report by February/March 1988.

The philosophical underpinnings of the Green Paper were explicit with its linking education to the economy and the observation that education is about learning, in particular, learning that is related to future employment. The Green Paper was widely circulated, provoking intensive community discussion and debate, and resulting in over 600 written responses from a variety of interested stakeholders. ${ }^{47}$ However, despite such comprehensive feedback, commentators observed that there were virtually few differences between the original Green Paper and the final White Paper. ${ }^{48}$ Key themes of the White Paper are summarized below:

- Higher education is vital to preparing and skilling Australia's workforce and ensuring that the Australian economy remains globally competitive.

- There is a need to expand the sector and to provide opportunities for groups that have not traditionally participated in higher education.

- There is a need to increase funding for the sector, and no further funding would be coming from the government.

- There is a need to recognize the private benefits of education and for individuals to pay their 'fair share' of the costs.

- The system needs to be more flexible, with more secure and larger institutions. 
- A renewed emphasis on areas of study important for economic growth, such as computer science, business studies and engineering.

- The unified national system will result in institutions funded on merit and achievement rather than history and reputation.

- Changes to staffing, including how staff are recruited, promoted, managed and dismissed.

- Institutions need to be flexible, manage resources efficiently and effectively.

- Improved institutional management and an environment of productive competition between institutions. 49,50

Both the Green and White Papers used powerful metaphors to help persuade sceptics of the compelling rationale for change. For example, Australia's higher education system was 'lagging behind international competitors'. This effectively framed the problem as a race, in which our competitors are leaving us trailing in their wake. The only possible answer to such metaphors is that we have to 'catch up' otherwise the problem will only get worse, and our rivals will increase their lead over us, further weakening our national economic well-being. ${ }^{51}$ Other examples include the metaphor 'middle class welfare' in relation to the need for tuition fees, implying a social injustice that the government would resolve; describing students as the 'private beneficiaries' of higher education, implying that some sections of society were receiving personal gains and private benefits. This clever use of language leads to the inescapable conclusion that from a distributive justice perspective, the less well-off were subsidizing the welloff, ${ }^{52}$ and this needs to be resolved by the individual beneficiary paying for their private benefits.

That Dawkins managed to successfully push his reforms through a sector that is notoriously resistant to change is a tribute to his strategic skills, and his rapid release of major policy documents. The Green Paper was released within only 12 weeks of Dawkins taking over the portfolio and the timing was rather fortuitous with December being the period in which the university system slows down in preparation for the annual holidays. The views of the higher education community and other interested parties were to be submitted by the end of April 1988. With January effectively 'wiped out' for the holidays, and with most universities not fully on board until mid to late February, this left little time for deep discussion. As has been noted elsewhere, the quick release of the Green and White Papers, massive reform agenda, that included both macro-level initiatives, such as student funding, the unified national system, as well as micro-level issues, such as probationary periods for staff, 'kept his potential critics off-balance and in reactive mode.' 53 
Moreover, through proposing to abolish the binary system between the universities and the colleges, Dawkins played off one group against another. The abolition of the binary system and the creation of the new 'unified system' were of far-reaching significance for the sector. The former colleges of advanced education were keen to embrace the university title and other benefits of being a university. For the existing universities, there was little choice but to accept the unified national system. The rather unattractive alternative was to exist outside the system that would result in diminished access to government funding.

The new unified national system saw 19 universities and 46 colleges of advanced education, along with a number of small specialist institutions undergo a series of 'marriages' or mergers, resulting in the creation of 36 universities. Although this seems heavy handed, the distinction between the universities and the colleges had already been blurring with the colleges offering courses normally offered only in the universities, as well as staff in the colleges undertaking academic research. Despite receiving over 600 written submissions there were few substantive changes to the overall policy framework. The standing joke amongst the academic community at the time was 'how do you turn a Green Paper into a White Paper? Just photocopy it!' 54 In short, it was a political masterstroke.

The report of the Wran Committee on Higher Education Funding was released in April 1988 and recommended the introduction of a tuition fee known as the Higher Education Contribution Scheme (HECS). This major shift in government higher education policy met with resistance from students and other interested groups but despite this was implemented in January 1989. In brief, the scheme required students to make a financial contribution towards the cost of their study, payable through the taxation system once a certain threshold was reached. Students could also receive a 15 per cent discount for paying upfront. In essence, the establishment of HECS created the 'individual consumer' 55 and the previous 15 years of free higher education had come to an abrupt halt. ${ }^{56}$ More importantly, there would be no going back. The financial burden on the taxpayer had been reduced, the individual as a private beneficiary of higher education had been firmly established and future governments, both Labour and Liberal, have shown a strong commitment to the HECS system. Indeed, it has been pointed out that there is little substantive difference between the two major parties over the direction of higher education, save from a few minor details, with a common consensus that the 'invisible hand' of the market will create the necessary adjustments. ${ }^{57}$ 


\section{THE WEST REPORT 1998}

In 1997 the Liberal government of Australia appointed a committee to review Australia's higher education system, with the goal of addressing the following three broad areas:

1. Reviewing the higher education sector and determining whether it was effective in meeting the social, economic, scientific and cultural needs of the nation.

2. Developing policy that will ensure universities are responsive to change, and meet the needs of students, industry and society.

3. Identify options for the financing of higher education. ${ }^{58}$

Roderick West, a retired Sydney private school headmaster, was chosen to chair the committee. The review team visited all 36 public universities, and presented its final report to the Minister in April 1998..$^{59}$ The report covered a range of issues facing higher education, and similar to previous reviews, it framed the review with reference to external forces threatening higher education. The 'sense of urgency' 60 that the report noted was due to a policy framework that will not cope with a fast changing world; increasing expectations from the community, such as students, parents and employers; demand from both domestic and international students; the transformational power of the Internet and the World Wide Web; and the threat of increased competition both from existing providers and also from new entrants in associated industries. ${ }^{61}$

The report adopted a 'consumerist' approach to higher education, pointing out the 'perversity' of existing incentive schemes to ensure that universities satisfy the needs and preferences of students, and that 'many of the current practices in Australian higher education would not have survived in an open market - students would have voted with their feet long ago'. ${ }^{62}$ The West Report was written with an eye to the vernacular of the business world, using phrases such as 'industry', 'consumer protection', 'competition' and 'student centred'. Clearly, this was a report that viewed the universities as providers of a service, and the students as the consumers of that service. What was needed, argues the report, was a mechanism to facilitate the relationship between provider and consumer, and that mechanism was to be the creation of 'an economic market in higher education'. ${ }^{63}$

Of the 36 recommendations made by the West Report, arguably the most controversial was the proposal for a funding and policy framework that placed the student at the centre of the system. Under this proposal, university funding for tuition would be more closely aligned with 
demand. All school leavers and adults accessing education for the first time would have a lifelong learning entitlement, which could be used by the student to purchase educational services. Prospective students would be able to make a more informed choice with access to comprehensive information about courses and institutions, and they would also receive 'protection' with a stronger accreditation system and concerted efforts to improve teaching. ${ }^{64}$

The report stopped short of recommending a fully market based model, insisting that while institutions could set their own tuition fees, the government would set an upper limit for students receiving a government supported place. However, the report argued for a semi-market based model, recommending that universities can admit full fee paying local students who are not allocated a subsidized place. Recognizing that the power relationship between the universities and the student is heavily one sided, the report also recommended 'an independent complaints procedure to ensure that students are able to gain redress should providers not satisfactorily deliver studies or services to them' ${ }^{65}$ The report also recommended that government accredited private providers would receive government subsidized places, signalling that the sector could benefit from increased competition.

The reactions to the report were 'negative, and disappointing, but also predictable'. ${ }^{66}$ Some vice chancellors viewed the student centre funding proposal as being ideologically driven, with one vice chancellor calling the discussion paper that foreshadowed the report 'desperately shallow ... where high quality institutions are transformed to narrowly defined schools catering for the needs of their customers' ${ }^{97}$ The National Tertiary Education Union stated that the report was regressive and a threat to the higher education sector ${ }^{68}$ while others argued that the student centred funding model would inevitably lower standards and decrease opportunities to access higher education. ${ }^{69}$

When contrasted with previous government funded reports on the higher education sector, the proposals in the West Report are arguably the most radical, with one commentator stating that 'the West committee has provided governments with a conceptual basis for increasing private fees up to the level of full $\operatorname{cost}^{\top}{ }^{70}$ with subsidies available on an equity basis. It is clear that in the view of the West committee, the long-term objective for Australian higher education was a completely deregulated sector, driven by the laws of supply and demand, in which the student consumer was sovereign. Rather surprisingly, the then Minister, David Kemp, rejected the voucher proposal outright, and the government provided little in the way of a response to the West Report. However, in 1999, Minister Kemp dusted off some of the key ideas contained in the West Report and 
repackaged them in a submission to Cabinet, where he proposed, amongst other things, abolition of current controls over the numbers of places a university can offer; student fees for tuition set by providers, a universal loans scheme to help students pay tuition costs, with a real rate of interest, and revised quality assurance arrangements that facilitate the entry of new players. ${ }^{71}$ However, following strong criticism from the sector and the Labour Party, the Prime Minister rejected the bulk of Kemp's proposals, in particular, the deregulation of fees. Despite this, the West Report is important because it raised the issue of fee deregulation that some sections of the higher education sector, noticeably the elite universities, not to mention fiscally constrained governments, find appealing.

In the following section we provide a brief discussion of recent policy initiatives in Australian higher education, focusing upon the government's response to the Bradley Review of Higher Education, which, with its primary focus upon the student as consumer brought the sector one step closer to a purely market driven model of higher education.

\section{THE BRADLEY REVIEW OF AUSTRALIAN HIGHER EDUCATION 2008}

The Bradley Review of Australian Higher education was established by the Labour government to examine whether the "higher education sector is structured, organised and financed to position Australia to compete effectively in the new globalised economy'. ${ }^{72}$ Similar to the impetus behind the Dawkins Green Paper, and the West Report, the Bradley Review was in part a response to a growing fear that Australia was falling behind other countries in the region that had already undertaken significant reforms and investment in higher education. The review acknowledges that although Australia is endowed with natural resources, there are no guarantees that Australia will continue to thrive. Written against a background of the global financial crisis, the review points out the speed and impact such events can have upon the Australian economy. The antidote to coping with such global forces is a workforce that has well-educated citizens, who are 'resilient, informed, adaptable and confident' ${ }^{73}$ The source for such welleducated citizens is a strong, equitable education system, allowing each individual to fulfil their aspirations.

The Bradley Review summarizes the previous two decades of policy direction in Australia thus:

- Increasing the percentage of the population participating in higher education. 
- Increasing the diversity of university income sources, including from international students.

- Increasing the contribution by students to the cost of their education.

- Improving productivity and efficiency in higher education.

- Introducing competitive or performance based funding.

- Diversifying higher education by government support for private provision. ${ }^{74}$

Despite such initiatives, which arguably conferred a 'first mover advantage', ${ }^{75}$ the review notes that other countries have also managed to make similar improvements to their higher education systems and that the recommendations of the review would only be enough to keep Australia from lagging behind.

Some of the key issues and challenges for Australia identified by the review were in brief:

- Australia is 9th out of 30 in the proportion of people aged 25-34 with a degree, down from 7 th a decade ago.

- Other Organisation for Economic Co-operation and Development (OECD) countries have targets of up to 50 per cent, placing Australia in a competitive disadvantage.

- The supply of people with undergraduate qualifications will not keep up with workforce demand, and there is a need to source new undergraduates from under-represented members within society, such as people with low socio-economic status, indigenous people and those from regional and remote areas.

- The move from elite to a mass system (as per the Dawkins reforms) has created greater diversity in the student body.

- There are signs that the quality of the educational experience is declining. For example, the UK results of the Course Experience Questionnaire (CEQ) in 2005, 2006 and 2007 were between 14 per cent and 15 per cent higher than the Australian results. Similarly, the Australian results from the Australasian Survey of Student Engagement (AUSSE) are much lower than those of the USA and Canada.

Given the challenges facing Australia, the review made the following key recommendations:

- Agreeing upon a target of 40 per cent of 25-34 year olds obtaining an undergraduate degree, by 2020. 
- By 2020, 20 per cent of undergraduate students should be from low socio-economic backgrounds.

- Funds follow the student and not the institution. That is, all qualified individuals will have an entitlement to undertake an undergraduate qualification.

- A national system for accreditation of higher education providers, both public and private, will be developed to ensure the quality of the deregulated system.

- That all higher education providers be required to administer the Graduate Destination Survey, Course Experience Questionnaire and the Australasian Survey of Student Engagement and report annually on the findings.

The 46 recommendations of the Bradley Review were well received with the government, providing a supportive initial response in March 2009, Transforming Australia's Higher Education System. As with previous reports, the government response acknowledged the relationship between Australia's economic prosperity and the need to produce a highly skilled workforce. Given this, the government made the remarkable decision to undertake a radical overhaul of the student funding system. In contrast to the previous model that placed a limit or 'caps' on the number of places a university can offer, the government announced that from 2012 Australian universities would be funded for student places on the basis of student demand. According to the government, the new system would encourage universities to be more responsive and also to differentiate themselves in order to attract students. ${ }^{76}$ The estimated increase in enrolments expected as a consequence of this policy shift was 80,000 new places from 2010 to 2013. To ensure both transparency and quality of the higher education sector, the government established the Tertiary Education Quality and Standards Agency (TEQSA) that is responsible for ensuring that Australia's students receive a high quality education from the institution they enrol in.

The significance of the Bradley Review was not lost on the sector, with some commentators calling it a 'milestone'. ${ }^{77}$ In other circles, the government's response to the review, in particular the funding follows the student model, was likened to when the Australian dollar was floated on world markets; such is the significance of this simple, but profound policy change. ${ }^{78}$ The ramifications of the demand driven system are also profound. Universities would receive funding based upon how many students they enrol. Universities that are successful will be rewarded accordingly. Universities that are unable to compete will either merge with other institutions or be forced to close down.

In the following section we provide a brief discussion regarding recent 
changes to the higher education sector in the UK. In particular, we examine the Browne Report of higher education funding and student finance and the government's response to the report.

\section{THE UNITED KINGDOM}

In 2009, the Labour government commissioned the Browne Report into higher education funding and finance. Lord Browne was a highly successful businessman having been the Chief Executive Officer (CEO) of British Petroleum. Other members of the seven-person committee included the head of McKinsey's Global Education Practice, a former Treasury economist and a banker. ${ }^{79}$ The Browne committee was tasked by the Labour government with reviewing the funding of higher education in the UK and to make recommendations to ensure the financial sustainability of higher education institutions, high quality teaching and a higher education sector that is accessible to all members of society with the ability to participate. The committee submitted its report to the newly formed Coalition government in October 2010.

Similar to government reviews of higher education in Australia, the Browne Report begins by noting that higher education contributes to the economic prosperity of the country, as well as conferring private benefits on the individuals who receive tertiary qualifications. These private benefits come in the form of higher salaries, improved job prospects, better health and increased social status. In sum, graduates have better life prospects than non-graduates.

The Browne Report draws on a number of indicators to make the case that unless there is increased investment in higher education the future wellbeing of the UK is at risk. In brief, the report argues that other countries are moving ahead of the UK on measures of productivity and competitiveness, placing the UK at a competitive disadvantage. ${ }^{80}$ The report also notes that higher education participation rates in the UK are beginning to fall behind a large number of countries, further placing the UK in a vulnerable position. Unless participation rates are expanded, argues the report, the UK will 'get stuck in a low skill equilibrium where a substantial part of the economy produces low specification goods and services, which are sold on the basis of low price, and which can only support relatively low paid jobs' ${ }^{81}$ The report notes that some countries have introduced tuition fees to fund the higher education sector. In summarizing, the Browne Report states that there is a pressing need to develop a sustainable funding solution for higher education taking into account that government expenditure on higher education is expected to reduce significantly. 
In evaluating the system of higher education in the UK, the Browne Report made the following key points:

- Public investment in higher education has not kept up with demand.

- The principle of a deferred graduate contribution to tuition costs was first considered in the Robbins Report on Higher Education in 1963.

- The introduction of student fees in 2006 has not had a negative impact on full-time participation rates, which is consistent with evidence from overseas.

- There is general consensus amongst the key stakeholders in higher education that those who benefit directly from higher education as graduates should make a financial contribution to the costs.

- Student expectations have increased, although there is no empirical evidence that quality has increased as a result of the additional student fee income. Moreover, there are few incentives for institutions to improve the student experience.

The key elements of the Browne Report can be summarized thus:

- Students will have to pay more for their education. Universities that charge more than $£ 6,000$ a year will have to give a proportion of their extra income to supporting poorer students. Those universities that charge more than $£ 7,000$ per year will have to widen access.

- Students should be at the heart of the system. Armed with better information, student choice will determine which courses are offered and by which institutions. Student choice will drive educational quality.

- There will be no cap on student numbers at university.

- There will be no upfront costs for students regardless of mode of study. Those earning lower incomes will pay less and those earning higher incomes will pay more.

- The Higher Education Council will regulate competition to ensure positive outcomes for students and taxpayers.

- In the new competitive environment, there will be winners and losers. Some institutions will be successful while others may fail and be forced to merge or close down. 


\section{THE GOVERNMENT RESPONSE TO THE BROWNE REPORT}

The response from the Coalition government was made explicit with the title 'Higher Education: Students at the Heart of the System'. If universities were unsure as to the philosophy that would underpin the government's position, the foreword made it clear that the government wanted a higher education system that is more accountable to students and the taxpayer; and a system that places as much emphasis on teaching as it does research. Adopting the model of the student as consumer, the foreword discusses 'empowering prospective students' by ensuring access to better quality information; and a focus on student charters, student feedback and graduate outcomes. ${ }^{82}$ In general, the government's response to the Browne Report can be summarized as delivering a higher education system that views students as consumers, institutions as service providers and higher education as a predominantly private good. In this framework, institutions will only improve their offering if subjected to increased competition and a regulatory body that serves to protect the interests of the student consumer.

The key elements of the government's response to the Browne Report can be summarized thus:

- Higher education institutions will be able to charge a basic threshold of $£ 6,000$ per year for undergraduate courses up to a maximum of $£ 9,000$ per year.

- No student will have to pay upfront fees. Instead student loans will be available. Students will repay their loans at a rate of 9 per cent of earnings over $£ 21,000$. Graduate contributions will be based on a variable rate of interest related to income and capped at the retail price index (RPI) plus 3 per cent. Under this system graduates who become high earners will contribute the full cost of their tuition.

- Higher education institutions will provide standard information about their courses covering issues such as student workload per subject; teaching quality; student satisfaction; costs; employability of graduates; future earnings; the overall student experience; teaching qualifications and expertise of staff. According to the government the publication of such data will make it 'correspondingly harder for institutions to trade on their past reputations while offering a poor teaching experience in the present. Better informed students will take their custom to the places offering good value for money. 83

- Universities will be expected to publish summary reports of their student evaluation surveys on their own websites. 
- The government will consult on removing barriers to entry to the higher education sector. This includes allowing non-teaching institutions to award degrees, and changes to the criteria and process for determining which organizations are allowed to call themselves a university.

The response to the White Paper was mixed. Universities UK, representing the university sector, argued that some of the proposals in the White Paper would produce unintended consequences. ${ }^{84}$ The University of Cambridge argued that the White Paper lacked vision and a strategy for the sector, and that higher education should not be reduced to a utilitarian equation of cost and personal financial benefit. The University of Oxford argued against the student as consumer model, stating that students and universities are partners in learning..$^{85}$ Conversely, others argued that the White Paper does not go far enough and that the proposals still guarantee universities a quota of 95 per cent of their current enrolments, thus creating little incentive to improve quality. ${ }^{86}$

More recently in the UK, the higher education sector received $£ 150$ million less for teaching grants, in response to budgetary cutbacks. In writing to the Higher Education Funding Council, the Secretary of State for Business stated that 'I am making these savings against a background of an overall rise in institutional income from fees: I estimate that institutions could earn over $£ 8$ bn from students subject to regulated fees in 2015-16 and some $£ 9$ billion in 2016-17. ${ }^{87}$ In other words, the government may be granting you less money, but you are quite capable of making up the shortfall.

\section{SUMMARY AND CONCLUSION}

It is quite clear from the above discussion that there is a persistent push by governments of all persuasions towards treating students as consumers of higher education and universities as service deliverers. The introduction in Australia of the Higher Education Contribution Scheme (HECS) radically altered the relationship between universities and students. By attaching a fee to the education of students, and emphasizing the point that education is a private good, with the individual the main beneficiary, the government transformed students into consumers. Students were no longer simply studying for a degree. They were 'investing' in their own human capital, and as with any other investment, they would expect a return for their patronage. According to the government, a university education was a very good investment as it 'promised' the recipient a higher 
salary than a non-university graduate. This argument had its genesis in the Martin Report of 1964, and was by now a firmly established belief. Thus, universities are, amongst other things, in the business of 'selling' improved life opportunities. Students are the buyers of this service, and like many other consumer purchases, there is no need for upfront payment, with the availability of HECS. The West Report in 1998 further cemented this notion, casting universities as service providers and students as consumers. The Bradley Review and the Browne Report in the UK further clarifies this perspective, with a semi-market model driven by student demand and preferences.

As with any relationship between buyer and seller, there is always the potential for problems to occur, especially when there are power asymmetries. Thus, governments in Australia and the UK have set up bodies to ensure quality of delivery of higher education and also offices to handle student complaints against universities who fail to deliver on the promises in the brochure and website. The implication of this being that government has little confidence in universities to act in the best interests of their students and so the need for an independent 'umpire' to ensure students are treated fairly.

The threat of competition to the economic well-being of the nation has caused governments to view higher education as a means to enhance the skills and intellectual capital of the nation. From the competition of the Soviet bloc in the 1960s to the threat of emerging countries in Asia, governments have reacted to the threat of external competition by turning to the higher education sector. In short, governments view education as being a deliverer of a highly skilled workforce in return for the investment made by government. Competition is also a driving force for change within the higher education sector. There is intense competition between the various universities for the most talented staff and students; competition between universities and private providers; and international competition between universities and offshore institutions that can enter overseas markets via online learning platforms.

The transformation of the student into a consumer of higher education along with an increase in the competitive landscape for higher education is irreversible. There is little prospect of governments increasing funding to the higher education sector, especially in fiscally constrained environments. Governments will nevertheless expect the higher education sector to deliver a highly skilled workforce and be accountable to the taxpayer and the student consumer. For those institutions that wish to survive and prosper in this environment they will need to accept that the relationship between student and universities continues to evolve into a market based consumer model. 
Although governments are keen to increase participation rates in higher education, this does not mean that the increase in students will mean that there will always be demand for all courses and all universities. In Australia recent data regarding graduate starting salaries makes sobering reading. Graduate starting salaries 'reached their lowest point relative to male average weekly earnings since the early 1980 s' ${ }^{88}$ Concomitantly graduate unemployment reached the highest level in the same period. Within Australia around 40 per cent of the 18-24 population receive an undergraduate degree. Unfortunately, the number of graduate-level vacancies has not kept pace with the number of graduates leading to the inescapable conclusion that (a) the reasons for attending university may not be as compelling as they once were; (b) choosing where and what to study is a very important decision in relation to returns on the 'investment'.

There will be fierce competition as each university struggles to differentiate itself in an increasingly competitive market, facing a paying, and more demanding customer. In the next chapter we examine in more detail the literature regarding the nature of competition in higher education.

\section{REFERENCES}

1. http://www.thecompleteuniversityguide.co.uk/university-tuition-fees/reddinsurvey-of-university-tuition-fees/foundation-undergraduate-tuition-fees$2014 \%$ E2\%80\%9315-ukeu/

2. http://parlinfo.aph.gov.au/parlInfo/download/legislation/billsdgs/3436314/ upload_binary $/ 3436314$.pdf;fileType=application $\% 2 \mathrm{Fpdf} \#$ search $=\% 22$ legisla tion/billsdgs/3436314\%22, p. 5 .

3. Stratford, M. (2013), 'Moving beyond Congress. Inside higher ed.', 11 October. https://www.insidehighered.com/news/2013/10/11/leaders-urge-researchuniversities-look-beyond-us-government-support

4. Carnegie Council (1980), cited in P. Coaldrake and L. Stedman (1998), On the Brink: Australia's Universities Confronting their Future, University of Queensland Press, St Lucia, Queensland.

5. http://sydney.edu.au/about/profile/history_origins.shtml

6. http://www.unimelb.edu.au/about/history/index.html

7. http://www.universitiesaustralia.edu.au/

8. Harman, G. (1984), 'Experience with co-ordinating agencies for tertiary education', Higher Education, 13, 5, pp. 501-15, p. 504.

9. Tompkins, P. (1958), 'Australian higher education and the Murray Report', Journal of Higher Education, 29, 7, pp. 361-8, p. 362.

10. Ibid., p. 361.

11. O’Brien, J. (1990), 'Universities, technology and academic work: a reconsideration of the Murray Committee on Australian universities (1957) in the light of Dawkins (1987-1988)', Journal of Tertiary Administration, 12, 1, pp. 255-72.

12. Submission by the AVCC, July 1957, CAU, Documents: All Universities, p. 7, cited in O’Brien (1990), p. 257. 
13. Tompkins, op. cit., p. 367.

14. Harman (1984), op. cit., p. 504.

15. Commonwealth Parliamentary Debates, 1957: 2676 and 2901, cited in Harman (1984).

16. Karmel, P. (1988), 'The role of central government in higher education', Higher Education Quarterly, 42, 2, pp. 119-33.

17. Tompkins, op. cit, p. 361.

18. Ibid., pp. 361-2.

19. Mahony, D. (1992), 'Establishing the university as the sole provider of higher education: the Australian experience', Studies in Higher Education, 17, 2, pp. 219-36.

20. Davies, S. (1989), The Martin Committee and the Binary Policy of Higher Education in Australia, Ashwood House. Melbourne, p. 33.

21. Mattarozzi Laming, M. (2001), 'Seven key turning points in Australian higher education policy 1943-1999', Postscript. http://www.edfac.unimelb.edu.au/ insight/pscript.shtml

22. Ibid., p. 247.

23. Ibid., p. 249.

24. Mahony, D. (1993), 'The construction and challenges of Australia's post-binary system of higher education', Oxford Review of Education, 19, 4, pp.465-83.

25. Meek, L. (1991), 'The transformation of Australian higher education from binary to unitary system', Higher Education, 21, 4, pp.461-94.

26. Mattarozzi, op. cit., p. 245.

27. Tertiary Education in Australia: Report of the Committee on the Future of Tertiary Education in Australia to the Australian Universities Commission, Vol. 1, Government Printer, Canberra. C6618/64.

28. Ibid., p. 12.

29. Smart, D. (1990), "The Dawkins "reconstruction" of higher education in Australia', Education Research and Perspectives, 17, 2, pp.11-22, p. 13.

30. Ibid., p. 12.

31. http://www.abc.net.au/pm/content/2005/s1313631.htm

32. Smart, D., R. Scott, K. Murphy and J. Dudley (1986), 'The Hawke government and education 1983-85', Politics, 21, 1, pp. 63-81.

33. Smart (1990), op. cit., p. 13.

34. Marginson, S. (2004), 'National and global competition in higher education', The Australian Educational Researcher, 31, 2, pp. 1-28, p. 2.

35. Smart (1990), op. cit., p. 13.

36. Smart, D. (1988), 'Shifting sands revisited: autonomy and independence in a climate of increasing government control', in Proceedings of the Seventh National Conference of the National Council for Independent Schools, Brisbane, October.

37. Dawkins, J. (1988a), 'Address', in G. Harman and V.L. Meek (eds), Australian Higher Education Reconstructed?, University of New England, Armidale, chapter 1, p. 15.

38. Smart (1990), op. cit., p. 14.

39. Dawkins, J. (1987), 'Higher education: a policy discussion paper', December, Australian Government Publishing Service, p. 2.

40. Mahony, D. (1994), "Government and the universities: the "new mutuality" in Australian higher education - a national case study', Journal of Higher Education, 65, 2, pp. 123-46. 
41. Dawkins (1987), op. cit., p. 3.

42. Ibid., p. 2.

43. Dawkins, J. (1988b), 'Higher education: a policy statement', July, Australian Government Publishing Service, p. 28.

44. Dawkins (1988b), op. cit., p. 35.

45. Smart (1990), op. cit., p. 15.

46. Marginson, S. (1997), Educating Australia: Government, Economy and Citizen Since 1960, Cambridge University Press, Cambridge, pp. 224-37.

47. Dawkins (1988b), op. cit., p. 3.

48. Smart (1990), op. cit., p. 16.

49. Dawkins (1988b), op. cit., pp. 5-12.

50. Harman, G. (1991), 'Institutional amalgamations and abolition of the binary system in Australia under John Dawkins', Higher Education Quarterly, 45, 2, pp. 176-98.

51. Bessant, J. (2002), 'Dawkins' higher education reforms and how metaphors work in policy making', Journal of Higher Education Policy and Management, 24, 1, pp. 87-99.

52. Ibid., p. 93.

53. Smart (1990), op. cit., p. 21.

54. Marginson, S. and M. Considine (2000), The Enterprise University: Power, Governance and Reinvention in Australia, Cambridge University Press, Cambridge.

55. Meek, op. cit.

56. Smart (1990), op. cit., p. 16.

57. Meek, op. cit. p. 470.

58. West, R. (1988), Learning for Life: Final Report, Department of Employment, Education, Training and Youth Affairs, Canberra, p. 1.

59. Harman, G. (1999), 'Vouchers or "student centred funding": the 1996-1998 Australian review of higher education funding and policy', Higher Education Policy, 12, pp. 219-35.

60. West, op. cit.

61. Ibid., pp. 17-18.

62. Ibid., p. 20.

63. Marginson, S. (1998), 'The West Report as national education policy making', Australian Economic Review, 31, 2, pp. 157-66.

64. Harman (1999), op. cit., p. 225.

65. West, op. cit., p. 27.

66. Harman (1999), op. cit., p. 228.

67. Osborne, M. (1997), 'About the report', La Trobe Bulletin, NovemberDecember, p. 4.

68. Illing, D. (1998), 'Kemp dumps unit vouchers plan', The Weekend Australian, April, pp. 18-19.

69. Harman (1999), op. cit., p. 230.

70. Marginson (1998), op. cit., p. 162.

71. Kemp, D. (1999), 'Proposals for reform in higher education', Leaked Cabinet Submission, Appendix 4 in Universities in Crisis, Report of the Senate Employment, Workplace Relations, Small Business and Education Committee, Parliament of Commonwealth of Australia. http:www.aph.gov.au/Senate/ committee/eet_ctte/completed_inquiries/1999-02public_uni_report/contents. htm, cited in J. Dudley (2009), 'Higher education, neo-liberalism and the 
market citizen', Unpublished $\mathrm{PhD}$ thesis, Murdoch University, Western Australia.

72. D. Bradley, P. Noonan, H. Nugent and W. Scales (2008), Review of Australian Higher Education, Final Report (Bradley Review), DEEWR, Canberra. http:// www.voced.edu.au/content/ngv\%3A32134.

73. Ibid., p. 1.

74. Ibid., p. 4.

75. Ibid.

76. Transforming Australia's Higher Education System (2009), Commonwealth of Australia.

77. Birrell, B. and D. Edwards (2009), 'The Bradley Review and access to higher education in Australia', Australian Universities Review, 51, 1, pp.4-13.

78. Davis, G. (2012). http://theconversation.edu.au/national-press-club-addressglyn-davis-on-the-quiet-revolution-in-higher-education-5748.

79. Collini, S. (2011), 'From Robbins to McKinsey', London Review of Books, 33, 16 , pp. $9-14$.

80. (2010), 'Securing a sustainable future for higher education: an independent review of higher education funding and student finance'. http://www.independent.gov.uk/browne-report, p. 16.

81. Ibid., p. 17.

82. Higher Education: Students at the Heart of the System (2011), Department for Business Innovation and Skills, June.

83. Ibid., p. 32 .

84. 'Universities UK: Response to the Higher Education White Paper' (2011). http://www.universitiesuk.ac.uk/highereducation/Documents/2011/Response ToTheHigherEducationWhitePaper.pdf

85. Baker, S. (2011), 'Cambridge and Oxford savage higher education White Paper', Times Higher Education, 30 September. https://www.timeshighereducation.com/news/cambridge-and-oxford-savage-higher-education-whitepaper/417622.article

86. Leunig,T.http://blogs.lse.ac.uk/politicsandpolicy/2011/06/28/higher-educa tion-white-paper/

87. http://www.hefce.ac.uk/media/HEFCE,2014/Content/News/2015/grant_ letter_21_july_2015.pdf

88. Dodd, T. (2015), 'How jobs scramble is taking gloss off university degrees', Australian Financial Review, 27 July, p. 11. 